\title{
Inhibitory effects of tamoxifen and doxorubicin, alone and in combination, on the proliferation of the MG63 human osteosarcoma cell line
}

\author{
ZHENG-XIAO OUYANG and XIAN-AN LI \\ Department of Orthopaedics, Hunan Provincial Tumor Hospital and Tumor Hospital of Xiangya School of Medicine, \\ Central South University, Changsha, Hunan 410013, P.R. China
}

Received January 29, 2013; Accepted July 10, 2013

DOI: $10.3892 / \mathrm{ol} .2013 .1487$

\begin{abstract}
The present study aimed to compare the combined effect of tamoxifen (TAM) and doxorubicin (ADM) with the individual effects of TAM and ADM alone on the MG63 human osteosarcoma cell line. Estrogen receptor (ER) expression was detected in the MG63 cells using reverse transcription PCR. The morphological changes during the inhibition of cell growth were observed using an inverted microscope and a 3-(4, 5-dimethy1-2-thiazol-2-yl)-2,5-diphenyl-tetrazolium bromide (MTT) colorimetric assay following the individual or combined addition of TAM and ADM. ER $\alpha$ and ER $\beta$ expression was detected in the MG63 cells. The typical apoptotic cell morphology was observed in all groups, with the exception of the control group. The MTT colorimetric analysis demonstrated that the rate of inhibition of cell proliferation in the combination group was significantly increased compared with that in the other groups $(\mathrm{P}<0.05)$. ER $\alpha$ and $E R \beta$ expression was detected in the MG63 human osteosarcoma cells. TAM and ADM alone were able to inhibit cell proliferation. The combination of TAM and ADM significantly enhanced the inhibitory effect, partly through the enhanced sensitivity of the cells to ADM by TAM, which caused the inhibition of cell proliferation and apoptosis.
\end{abstract}

\section{Introduction}

Osteosarcoma is the most common primary tumor of the bone. Patients with the condition had a poor prognosis until the 1970s. Major progress was made with the introduction of neoadjuvant chemotherapy, which combines doxorubicin (ADM), cisplatin, methotrexate and/or ifosfamide, resulting in

Correspondence to: Professor Xian-An Li, Department of Orthopaedics, Hunan Provincial Tumor Hospital and Tumor Hospital of Xiangya School of Medicine, Central South University, No. 283 Tongzipo Road, Changsha, Hunan 410013, P.R. China E-mail: terryoy@qq.com

Key words: osteosarcoma, estrogen receptor, tamoxifen, doxorubicin a 5-year survival rate of $60-70 \%$ (1-4). However, the rates have not improved further (5). Certain patients, including 74\% with lung metastases at the time of diagnosis, have a poor response to neoadjuvant chemotherapy (6), in which treatment-related toxicity and mortality are the main limiting factors allowing no further treatment intensification. Furthermore, a higher dosage of chemotherapy has been shown to result in more long-term complications, including cardiac failure $(7,8)$. Human osteoskeletal non-neoplastic and neoplastic disorders are diseases in which gender differences are markedly noted in the incidence and development. The highest incidence of osteosarcoma is observed in a younger patient group with high levels of sex hormone and sex steroid receptor activity. Estrogen receptors (ERs) have been sporadically reported in human osteosarcoma or its cell lines. Sex steroids and receptors play significant roles in the regulation of cell proliferation in human osteosarcoma.

Tamoxifen (TAM), a selective ER modulator (SERM), has been used widely as the first-line drug of breast cancer chemotherapy with little side effects (9). Studies have shown that TAM may have the ability to enhance the relative sensitivity of tumors of non-sex-hormone-targeted organs to chemotherapeutics (10). As TAM and ADM have antitumoral properties, a combination of these medications may be an option in the therapy of osteosarcoma. However, no data regarding their potential synergistic effects are currently available. Therefore, the present study examined ER expression in the MG63 human osteosarcoma cell line and compared the combined effect of TAM and ADM with the individual effects of TAM and ADM in MG63 human osteosarcoma cells.

\section{Materials and methods}

Cells and cell culture. The MG63 human osteosarcoma cell line was provided by the Chinese Academy of Science (Shanghai, China). The cells were cultured in Dulbecco's modified Eagle's medium (DMEM), supplemented with $10 \%$ fetal calf serum and antibiotics, at $37^{\circ} \mathrm{C}$ in a humidified atmosphere with $5 \%$ $\mathrm{CO}_{2}$. All cell culture reagents were purchased from Gibco Co., Ltd. (Carlsbad, CA, USA).

Analysis of ER mRNA expression. Due to the low expression of ER in osteoskeletal cells (11) and the difficulty in 
examining ER through immunohistochemistry, reverse transcription (RT) PCR for ER $\alpha$ and ER $\beta$ was performed on the MG63 cells. Total RNA was extracted using TRIzol (Invitrogen Life Technologies, Carlsbad, CA, USA) from the MG63 cells according to the manufacturer's instructions. First-strand cDNA was synthesized from $1 \mu \mathrm{g}$ total RNA by reverse transcription using oligo-dT primers and reverse transcriptase (Invitrogen Life Technologies) according to the manufacturer's instructions. cDNA was utilized as a template for the amplification of full-length ER $\alpha$ and ER $\beta$ using the following primers: 5'-TTGCTATGTTACTAAGCGTGAG-3' for ER $\alpha$ and 5'-GATGCTTTGGTTTGGGTGATT-3' for ER $\beta$. PCR was performed in $50 \mu \mathrm{l}$ volumes containing $1 \mu \mathrm{l}$ cDNA, $1 \mu \mathrm{l}(10 \mu \mathrm{M})$ of each primer and $4 \mu \mathrm{l}(2.5 \mathrm{mM})$ of each dNTP in a reaction buffer containing $1 \mu \mathrm{l}(2.5 \mathrm{u} / \mu \mathrm{l})$ Taqplus (Invitrogen Life Technologies). The thermocycling conditions consisted of an initial incubation step at $95^{\circ} \mathrm{C}$ to activate the polymerase enzyme, followed by 35 cycles consisting of $45 \mathrm{sec}$ at $95^{\circ} \mathrm{C}, 45 \mathrm{sec}$ at $60^{\circ} \mathrm{C}$ and $45 \mathrm{sec}$ at $72^{\circ} \mathrm{C}$. The PCR products were separated in $2 \%$ agarose gels and visualized by ethidium bromide staining. The housekeeping gene, $\beta$-actin (5'-AGGGGCCGGACTCGTCATACT-3'), was used as a control.

Drugs and drug treatment. The MG63 cells were divided into three groups according to the incubation time (24, 48 and $72 \mathrm{~h}$ ). Each group was treated with various concentrations of TAM (First Pharmaceuticals, Hangzhou, China) and ADM (Farmitalia Carlo Erba, Milan, Italy). According to the clinical serum concentrations of the two drugs, concentrations of 0.1 , 1,5 or $10 \mu \mathrm{g} / \mathrm{ml} \mathrm{ADM}$ and $1,2,5$ or $10 \mu \mathrm{mol} / 1$ TAM were used for the individual groups, while $5 \mu \mathrm{g} / \mathrm{ml} \mathrm{ADM}$ and $5 \mu \mathrm{mol} / 1$ TAM were used for the AT (ADM and TAM) combination group.

Morphological changes of cell growth inhibition. The MG63 osteosarcoma cells were cultured to the exponential phase of growth and the cell number was adjusted to $1.0 \times 10^{5}$ cells $/ \mathrm{ml}$ and seeded in $25-\mathrm{cm}^{3}$ tissue culture flasks. Subsequent to the cells being incubated for $24 \mathrm{~h}$, the medium was replaced by a culture medium that contained the various concentrations of drugs, and the cells were incubated for another 24, 48 and $72 \mathrm{~h}$. The morphological changes during cell growth inhibition were observed using an inverted microscope.

\section{3-(4,5-Dimethyl-2-thiazol-2-yl)-2, 5-diphenyl-etrazolium} bromide (MTT) activity measurement. The MTT assay is a colorimetric measurement of MTT reduction to a blue formazan product by mitochondrial dehydrogenases of viable cells (12). The cells were seeded in 96-well plates at a density of $5 \times 10^{3}$ cells/well and incubated for $24 \mathrm{~h}$. Thereafter, the medium was replaced and incubation continued for a further 24, 48 and $72 \mathrm{~h}$ in the presence or absence of the test compounds of the various concentrations of the drugs. The medium was replaced and $50 \mu \mathrm{l}$ MTT (Sigma Chemical Co., St. Louis, MO, USA) working solution was added to each well at a final concentration of $0.5 \mathrm{mg} / \mathrm{ml}$. The cells were incubated for $4 \mathrm{~h}$ at $37^{\circ} \mathrm{C}$ and the medium was changed to $100 \mu \mathrm{l}$ dimethyl sulfoxide to dissolve the formazan. Optical density (A) was measured at $492 \mathrm{~nm}$ of the wave length using a Tecan Spectrafluor Plus

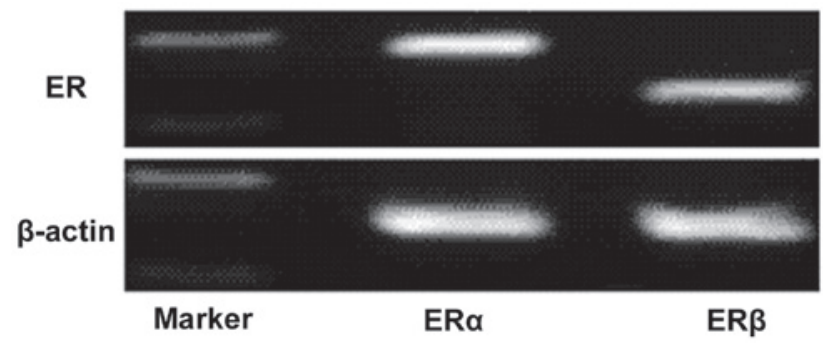

Figure 1. RT-PCR analysis of ER (top) and $\beta$-actin (bottom) in MG63 cells. $\mathrm{RT}$, reverse transcription; ER, estrogen receptor.

microplate spectrophotometer (Esbe Scientific Industries Inc., Ontario, Canada). Each experiment was performed in triplicate. The medium of the control group was replaced by DMEM supplemented with $10 \%$ fetal calf serum and antibiotics. The quantity of viable cells was reflected by the cell growth inhibition rate that was calculated using the following formula: Cell growth inhibition rate $(\%)=(1-$ optimum $\mathrm{A}$ of experimental group / optimum A of control) x 100 .

Statistical analysis. The results are expressed as the mean \pm standard error. The data were evaluated by a multivariate analysis of single variance with repeated measures designs. Multiple comparisons were performed using one way analysis of variance (ANOVA) by a Student-Newman-Keuls test. For each variable, at least three independent experiments were performed. All analyses were performed using SPSS 20.0 software (SPSS, Inc., Chicago, IL, USA). P<0.05 was considered to indicate a statistically significant difference.

\section{Results}

ER expression in MG63 cells. RT-PCR analysis of mRNA that was isolated from the MG63 human osteosarcoma cell line indicated the presence of ER $\alpha$ and ER $\beta$ mRNA in the MG63 cells, suggesting that ER $\alpha$ and $E R \beta$ are constitutively expressed by the MG63 human osteosarcoma cell lines (Fig. 1).

Morphological analysis of MG63 cells with various drug intervention. Typical apoptotic cell morphology was observed in all the groups, with the exception of the control group. The images show that the cells grew well in the control group, and were mostly spindle-shaped and large, with uniform round nuclei and clear cytoplasm. It was identified that $24 \mathrm{~h}$ following the administration of TAM $(5 \mu \mathrm{mol} / \mathrm{l})$, a small number of cells became round-shaped and multiplied slowly. With a prolonged amount of time and an increased drug concentration, more cells became round-shaped and dark. Additionally, the number of fragments increased and the sizes and amount of the plasma granules within the cells changed. Cell shrinkage and the formation of apoptotic bodies were observed. In the ADM group $(5 \mu \mathrm{g} / \mathrm{ml}, 24 \mathrm{~h})$, the typical early stage of cell apoptosis changes, including cell membrane budding and swollen organelles, were observed. The same morphological changes as previously described were observed in the combination group (AT) and the rate of apoptosis in the combination group was higher than that in the single drug groups under the same treatment times (Fig. 2). 
Table I. Cell growth inhibition rate of various concentrations of TAM (\%).

\begin{tabular}{|c|c|c|c|c|c|}
\hline \multirow[b]{2}{*}{ Time (h) } & \multicolumn{5}{|c|}{ Concentrations of TAM $(\mu \mathrm{mol} / \mathrm{l})$} \\
\hline & 0 & 1 & 2 & 5 & 10 \\
\hline 24 & 0 & $2.49 \pm 0.21$ & $8.80 \pm 0.56$ & $20.85 \pm 1.15$ & $31.52 \pm 1.54$ \\
\hline 48 & 0 & $5.68 \pm 0.32$ & $15.67 \pm 0.62$ & $39.57 \pm 0.61$ & $51.56 \pm 1.85$ \\
\hline 72 & 0 & $10.64 \pm 0.44$ & $30.38 \pm 0.76$ & $62.51 \pm 1.24$ & $69.40 \pm 2.24$ \\
\hline
\end{tabular}

TAM, tamoxifen.

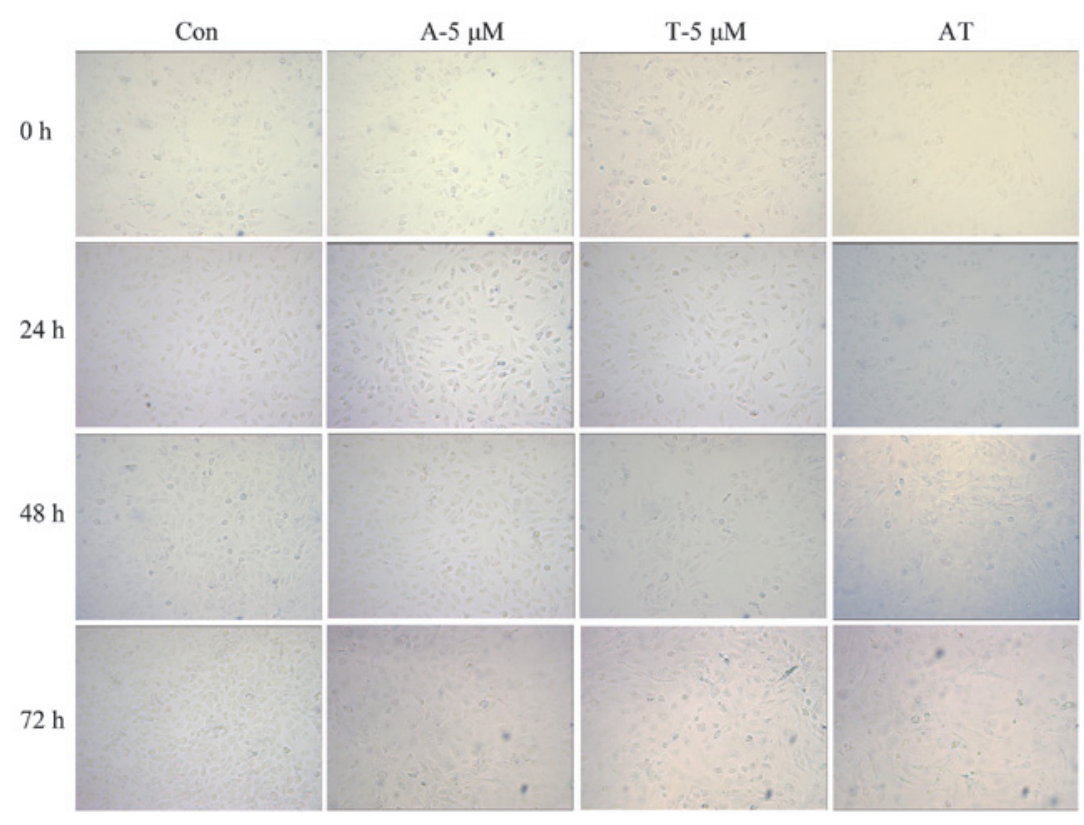

Figure 2. Morphological analysis of MG63 cells with various interventions of drugs. Con, control; A, ADM (doxorubicin); T, TAM (tamoxifen); AT, ADM and TAM.

MTT colorimetric analysis. It is well-known that the MTT reagent directly reacts with the mitochondria (mitochondrial dehydrogenase) of metabolically active cells. Therefore, the reaction of MTT reduction is directly proportional to the number of growing cells. The measured optical density is directly proportional to the number of viable cells in the culture medium. Therefore, MTT is regarded as a quantitative assay to determine the cytotoxicity of the materials and the viability/proliferation of the cells in solution in various groups.

Table I and Fig. 3 show the effect of TAM on the cell growth inhibition rate. According to the statistical analysis, the cell growth inhibition rates in the TAM groups gradually increased with a prolonged treatment time and increased drug concentrations. A significant difference was observed between the various groups with various times and concentrations. However, in the multiple comparisons, there were no significant differences between the 24- and 48-h, 1- and $2-\mu \mathrm{mol} / \mathrm{l}$ or 5- and $10-\mu \mathrm{mol} / 1$ groups $(\mathrm{P}>0.05)$. There were obvious dose-effect and time-effect associations in the MG63 cells that were treated with TAM.

Table II and Fig. 4 show the effect of ADM on the cell growth inhibition rate. The statistical analysis shows that the cell growth inhibition rates in the ADM groups gradually increased with a

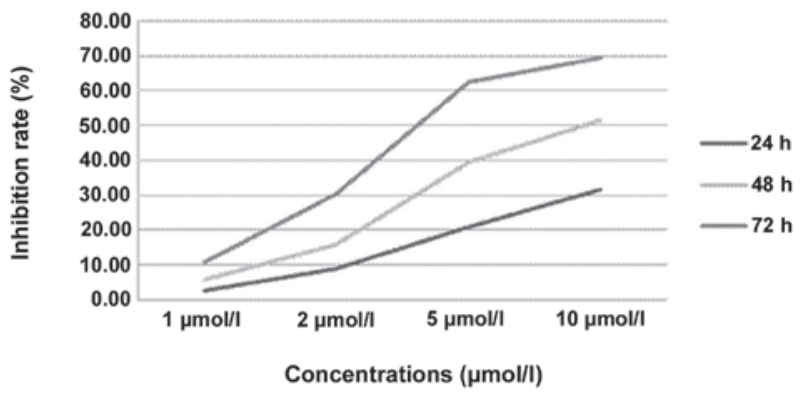

Figure 3. Effect of various concentrations and treatment time of TAM on MG63 cells. TAM, tamoxifen.

prolonged treatment time and increased drug concentrations. A significant difference was observed between the groups with the various times and concentrations. However, in the multiple comparisons, there were no significant differences between the 24- and 48-h, 72- and 48-h or 0.1- and 1- $\mu \mathrm{g} / \mathrm{ml}$ groups ( $\mathrm{P}>0.05)$. There were obvious dose-effect and time-effect associations in the MG63 cells that were treated with ADM.

Table III and Fig. 5 show the effects of TAM (5 and $10 \mu \mathrm{mol} / \mathrm{l}$, respectively), ADM (5 and $10 \mu \mathrm{g} / \mathrm{ml}$, respectively) 
Table II. Cell growth inhibition rate of various concentrations of ADM (\%).

\begin{tabular}{lccccc}
\hline & \multicolumn{5}{c}{ Concentrations of ADM $(\mu \mathrm{g} / \mathrm{ml})$} \\
\cline { 2 - 5 } Time $(\mathrm{h})$ & 0 & 0.1 & \multicolumn{1}{c}{1} & \multicolumn{1}{c}{5} & 10 \\
\hline 24 & 0 & $3.63 \pm 0.16$ & $8.75 \pm 0.93$ & $14.04 \pm 1.47$ & $31.78 \pm 1.68$ \\
48 & 0 & $7.65 \pm 0.41$ & $14.46 \pm 1.56$ & $25.53 \pm 2.07$ & $51.99 \pm 2.03$ \\
72 & 0 & $9.89 \pm 0.84$ & $21.76 \pm 1.89$ & $45.23 \pm 2.64$ & $68.95 \pm 3.65$ \\
\hline
\end{tabular}

ADM, doxorubicin.

Table III. Cell growth inhibition rates of single and combination drugs (\%).

\begin{tabular}{|c|c|c|c|c|c|c|}
\hline \multirow[b]{2}{*}{ Time $(\mathrm{h})$} & \multicolumn{6}{|c|}{ Concentrations (ADM, $\mu \mathrm{g} / \mathrm{ml}$; TAM, $\mu \mathrm{mol} / \mathrm{l})$} \\
\hline & 0 & TAM (5) & $\operatorname{ADM}(5)$ & AT (5 each) & TAM (10) & $\operatorname{ADM}(10)$ \\
\hline 24 & 0 & $20.85 \pm 1.15$ & $14.04 \pm 1.47$ & $49.17 \pm 3.21$ & $31.52 \pm 1.54$ & $31.78 \pm 1.68$ \\
\hline 48 & 0 & $39.57 \pm 0.61$ & $25.53 \pm 2.07$ & $68.33 \pm 1.90$ & $51.55 \pm 1.83$ & $51.99 \pm 2.03$ \\
\hline 72 & 0 & $62.51 \pm 1.24$ & $45.23 \pm 2.64$ & $85.27 \pm 2.15$ & $69.40 \pm 2.24$ & $68.95 \pm 3.65$ \\
\hline
\end{tabular}

TAM, tamoxifen; ADM, doxorubicin; AT, ADM and TAM.

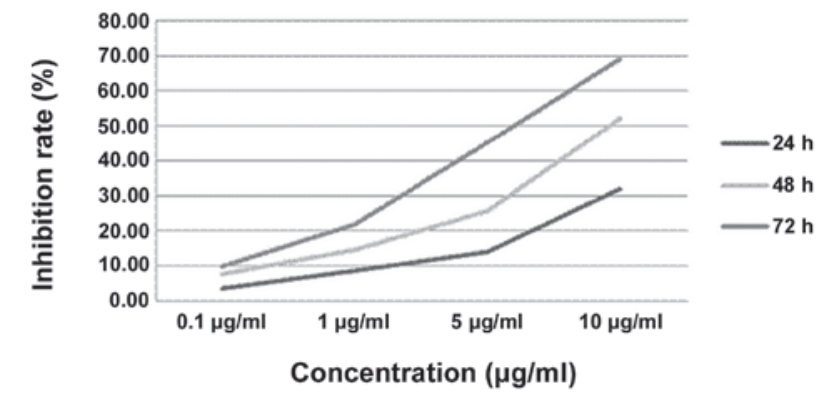

Figure 4. Effect of various concentrations and treatment time of ADM on MG63 cells. ADM, doxorubicin.

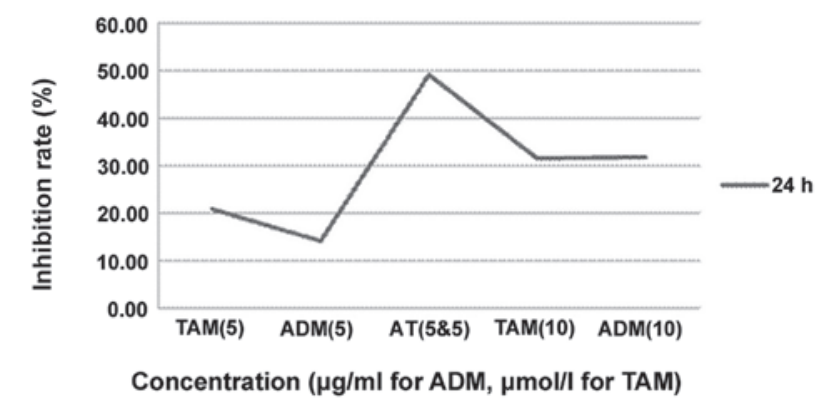

Figure 5. Effect of various concentrations and combination of drugs on MG63 cells. TAM, tamoxifen; ADM, doxorubicin; AT, ADM and TAM.

and AT (combination of $5 \mu \mathrm{mol} / 1 \mathrm{TAM}$ and $5 \mu \mathrm{g} / \mathrm{ml}$ ADM) on the cell growth inhibition rate. By the statistical analysis, the cell growth inhibition rates in the ADM groups gradually increased with a prolonged treatment time. A significant difference was observed between the group with various times and concentrations. However, in the multiple compari- sons, there were no significant differences between the TAM (5 $\mu \mathrm{mol} / \mathrm{l})$ and ADM $(5 \mu \mathrm{g} / \mathrm{ml})$ groups, TAM $(5 \mu \mathrm{mol} / \mathrm{l})$ and TAM $(10 \mu \mathrm{mol} / \mathrm{l})$ groups, TAM $(5 \mu \mathrm{mol} / \mathrm{l})$ and ADM $(10 \mu \mathrm{g} /$ $\mathrm{ml})$ groups and the TAM $(10 \mu \mathrm{mol} / \mathrm{l})$ and ADM $(10 \mu \mathrm{g} / \mathrm{ml})$ groups $(\mathrm{P}>0.05)$. The inhibition rate of the combination group was higher than that of the single drug groups, including the single drug groups with double the concentration.

\section{Discussion}

Non-neoplastic bone diseases, including osteoporosis and osteoarthritis, have a higher incidence in females, and osteoporosis may be treated and prevented using $17 \beta$-estradiol and raloxifene to a certain degree. Estrogen has been shown to play a significant role in the proliferation of bone cells (13). Furthermore, the highest incidence of osteosarcoma is observed in a younger patient group with a high level of sex hormone activity. Sex steroids and receptors play significant roles in the regulation of cell proliferation in human osteosarcoma.

Walker et al first reported the existence of sex steroid receptors in four cases of osteosarcoma from a dextran-coated charcoal assay (14). Stedman et al also identified ER proteins in osteosarcoma from gel filtration in the same year (15). These were the first studies to demonstrate the potential correlation between sex steroids and osteosarcoma. More recent studies on ER expression in osteosarcoma cases and cell lines are rare. The majority of the studies found that ER $\alpha$ and ER $\beta$ were expressed in human osteoblasts. The analysis of the ER subtypes reported by Chen et al demonstrated the dominance of ER $\beta$ in the MG63 cells (16). Dohi et al (17) reported that $\operatorname{ER} \beta$ was relatively widely distributed in the osteosarcoma cases and ER $\beta$ was the predominant ER that was expressed 
in the MG63 cells. In other osteosarcoma cell lines, including U2OS, ER $\alpha$ and ER $\beta$ mRNA has also been reported to be detected at a ratio of 1:4. (18) Solakidi et al reported that ER $\alpha$ was localized mainly in the nucleus of human U2OS osteosarcoma cells and ER $\beta$ was specifically enriched at the site of the mitochondria, but its significance has remained unknown at this juncture (19). The results of the present study revealed expression of ER $\alpha$ and ER $\beta$ mRNA in the MG63 cells, as detected by RT-PCR, which was consistent with those that have been reported previously. Therefore, the present study provides a basis for the endocrine therapy of osteosarcoma.

Furthermore, Dohi et al (17) reported that the proliferation of MG63 human osteosarcoma cells was stimulated by E2 and that the increment are significantly suppressed clinically using well-established blockers of a corresponding steroid that had been previously reported by Luo and Liao (20). These findings indicated the potential role of the ER in the pathogenesis and development of osteosarcoma. The steroid blockers have the potential to be used as suppressors of cell proliferation of human osteosarcoma cells. Therefore, estrogen is considered to exert effects not only on non-neoplastic bones but also on their neoplasms, particularly osteosarcomas.

As an ER antagonist, TAM is extensively used in the treatment of mammary adenocarcinoma. The most common side effect is vasomotor symptoms, which have been reported in $1-4 \%$ of cases. Toxicity and other side effects have been relatively uncommon during the clinical use of the TAM. TAM has been demonstrated to have biological and pharmacological activities beyond its traditional role as an anti-estrogenic agent. Among these are the inhibition of multidrug resistance (MDR) (21-23), protein kinase C (PKC) (24), calmodulin (25), insulin growth factor (26) and transforming growth factor- $\alpha$ (27). In addition, TAM has been associated with transforming growth factor- $\beta 1$ induction (28), immune reaction modulation (29), apoptosis induction $(30,31)$ and a reduction in the fluidity of the cytoplasmic membrane (32). It has been speculated that certain activities may be responsible for the unexpected therapeutic effect of TAM, alone or in combination with other anti-cancer drugs, in various cancers, including malignant melanoma $(33,34)$, brain glioma $(35)$ and lymphoma (36). In the present study, there were obvious dose-effect and time-effect associations in the MG63 cells that were treated with TAM. The therapeutic effect of TAM alone may be mediated by its non-specific effect on cytoplasmic membranes, as TAM, a triphenylethylene, is lipophilic and is expected to partition into hydrophobic domains in the fluid mosaic structure of cell membranes. Clark et al (32) have demonstrated previously that TAM, at concentrations of $>1 \mathrm{mM}$, significantly decreased the fluidity of the plasma membrane of ER ${ }^{-}$breast cancer cells and may have contributed to its non-ER-mediated cytotoxicity.

The analysis of sex steroid receptors in resected specimens of osteosarcoma cases and cell lines as a potential surrogate marker may be required in order to prepare for a potential endocrine therapy, particularly in the instance that the patients develop pulmonary metastasis and a poor response to the chemotherapy in their clinical course. Ferguson et al (37) reported that TAM showed the ability to enhance the survival rate of advanced breast cancer patients who had been treated with ADM in phase III. Studies have also indicated that the drug resistance of neuroblastoma, small cell lung cancer, gastric cancer, liver cancer, bladder cancer, ovarian cancer and epirubicin may all be reversed using TAM (38). The potential synergistic cytotoxic effect between TAM and chemotherapeutic agents in estrogen-independent solid tumors has been studied and documented $(31,39)$.

In an effort to increase the clinical efficacy of ADM, the present study determined whether the antitumor effects of this drug were able to be enhanced using a concurrent application of other drugs that have demonstrated anti-osteosarcoma activity, such as TAM. In the present study, the inhibition rates of the 24-h group of the MG63 human osteosarcoma cell line by $\operatorname{ADM}(5 \mu \mathrm{g} / \mathrm{ml})$, TAM $(5 \mu \mathrm{mol} / \mathrm{l}), \operatorname{ADM}(10 \mu \mathrm{g} / \mathrm{ml})$ and TAM $(10 \mu \mathrm{mol} / \mathrm{l})$ were $14.04,20.85,31.78$ and $31.52 \%$, respectively. By contrast, following the combination of TAM and ADM, the inhibitive rates increased to $49.17 \%$ and the results were consistent with those of the other groups, indicating that the effect of the chemotherapy drugs was enhanced by the cooperation of the two drugs and that TAM may enhance the effect of chemotherapeutics by comparing ADM and ADM mixed with TAM. The present analyses demonstrated that combination treatment of MG63 osteosarcoma cells exerts greater antiproliferative and apoptosis-stimulatory effects than treatment with the individual drugs alone.

Cancer cells may gradually develop a resistance to chemotherapeutic drugs in the course of chemotherapy and there have been numerous studies with regard to overcoming the resistance mechanisms (40). TAM, a cholangiocarcinoma sensitizer, may act as a P-glycoprotein (gp) substrate by competing for the P-gp binding site with antineoplastic agents. TAM inhibits the function of the transmembrane transporter and lowers the velocity of drug efflux from within cells, leading to an enhancement of the drug concentration and the effect of the chemotherapeutic drugs. Another underlying molecular event affecting this enhancement process appears to be the potent downregulation of $\mathrm{Bcl}-2$, a critical anti-apoptotic and chemoprotective protein. It has been well established that the ratio of the intracellular amount of the two proteins, Bcl-2 (antiapoptotic) and Bax (proapoptotic), is critical for subsequent cell survival and cell death $(41,42)$. Bax is the major apoptosis-promoting gene and may explain the synergistic cytotoxicity of TAM with ADM in the treatment of osteosarcoma. TAM also exerts a pleiotropic effect on intracellular growth and survival pathways, in particular the inhibition of PKC $(43,44)$, which is a growth-stimulatory kinase. Cheng et al (45) reported that high-dose TAM may potentiate ADM-induced apoptosis of hepatocellular carcinoma cells and this effect of TAM is associated with its inhibition on the membrane translocation of PKC- $\alpha$ and is not mediated by MDR inhibition. Biochemical modulation as a measure to improve systemic chemotherapy for osteosarcoma requires further investigation. Appropriate treatment strategies that are formulated according to the mechanisms of drug resistance and synergistic cytotoxic effects between TAM and ADM may be guides in the fight against cancer and thus require investigation. Due to the low prevalence rate of osteosarcoma, breakthroughs in new therapeutic approaches based on gene technology may be difficult.

To the best of our knowledge, no studies have been reported that are concerned with the use endocrine therapy for treating 
patients with osteosarcoma and that include an analysis of the synergistic cytotoxic effect on osteosarcoma cell lines between TAM and ADM. However, these studies should be pursued, particularly the molecular mechanism that is complicated by the fact that TAM is able to exert independent antitumor effects, considering the relatively poor clinical outcome of osteosarcoma patients with pulmonary metastases and a poor response to chemotherapy.

In conclusion, ADM, combined with TAM, is able to enhance the killing of tumor cells, and the addition of TAM may be a beneficial adjuvant to ADM-based chemotherapy in the treatment of osteosarcoma. Therefore, it may be worthwhile to consider this combination regimen for further evaluation in clinical trials. This information may be used to improve osteosarcoma treatment by reversing or reducing drug resistance, therefore supporting the notion that these drug combinations should be further evaluated in clinical trials.

\section{Acknowledgements}

The authors would like to thank The Second Xiangya Hospital of Central South University for technical assistance during this study.

\section{References}

1. Smith MA, Ungerleider RS, Horowitz ME and Simon R: Influence of doxorubicin dose intensity on response and outcome for patients with osteogenic osteosarcoma and Ewing's sarcoma. J Natl Cancer Inst 83: 1460-1470, 1991.

2. Lewis IJ, Nooij MA, Whelan J, et al; MRC BO06 and EORTC 80931 collaborators; European Osteosarcoma Intergroup: Improvement in histologic response but not survival in osteosarcoma patients treated with intensified chemotherapy: a randomized phase III trial of the European Osteosarcoma Intergroup. J Natl Cancer Inst 99: 112-128, 2007.

3. Graf N, Winkler K, Betlemovic M, et al: Methotrexate pharmacokinetics and prognosis in osteosarcoma. J Clin Oncol 12: 1443-1451, 1994

4. Delepine N, Delepine G, Bacci G, et al: Influence of methotrexate dose intensity on outcome of patients with high grade osteogenic osteosarcoma. Analysis of the literature. Cancer 78: 2127-2135, 1996.

5. Marina N, Gebhardt M, Teot L and Gorlick R: Biology and therapeutic advances for pediatric osteosarcoma. Oncologist 9: 422-441, 2004

6. Lewis VO, Raymond K, Mirza AN, Lin P and Yasko AW: Outcome of postradiation osteosarcoma does not correlate with chemotherapy response. Clin Orthop Related Res 450: 60-66, 2006.

7. Goldsby R, Burke C, Nagarajan R, et al: Second solid malignancies among children, adolescents, and young adults diagnosed with malignant bone turmors after 1976: follow up of a Children's Oncology Group cohort. Cancer 113: 2597-2604, 2008.

8. Mansky P, Arai A, Stratton P, et al: Treatment late effects in long-term survivors of pediatric sarcoma. Pediatr Blood Cancer 48: 192-199, 2007.

9. Zheng A, Kallio A and Härkönen P: Tamoxifen-induced rapid death of MCF-7 breast cancer cells is mediated via extracellularly signal-regulated kinase signaling and can be abrogated by estrogen. Endocrinology 148: 2764-2777, 2007.

10. Tan CK, Chow PK, Findlay M, et al: Use of tamoxifen in hepatocellular carcinoma: a review and paradigm shift. J Gastroentero Hepatol 15: 725-729, 2000.

11. Emst M, Parker MG and Rodan GA: Functional estrogen receptors in osteoblastic cells demonstrated by transfection with a reporter gene containing an estrogen response element. Mol Endocrinol 5: 1597-1606, 1991.

12. Carmichael J, DeGraff WG, Gazdar AF, et al: Evaluation of a tetrazolium-based semiautomated colorimetric assay: assessment of chemosensitivity testing. Cancer Res 47: 936-942, 1987.
13. Braidman IP, Davennport LK, Carter DH, et al: Preliminary in situ identification of estrogen target cells in bone. J Bone Miner Res 10: 74-80, 1995

14. Walker MJ, Chaudhuri PK, Beattie CW and Das Gupta TK: Steroid receptors in malignant skeletal tumors. Cancer 45: 3004-3007, 1980.

15. Stedman KE, Moore GE and Morgan RT: Estrogen receptor proteins in diverse human tumors. Arch Surg, 115: 244-248, 1980.

16. Chen FP, Hsu T, Hu CH, Wang WD, Wang KC and Teng LF: Expression of estrogen receptors alpha and beta in human osteoblasts: identification of exon-2 deletion variant of estrogen receptor beta in postmenopausal women. Chang Gung Med J 27: 107-115, 2004

17. Dohi O, Hatori M, Suzuki T, et al: Sex steroid receptors expression and hormone-induced cell proliferation in human osteosarcoma. Cancer Sci 99: 518-523, 2008.

18. Monroe DG, Secreto FJ, Subramaniam M, Getz BJ, Khosla S and Spelsberg TC: Estrogen receptor alpha and beta heterodimers exert unique effects on estrogen- and tamoxifen-dependent gene expression in human U2OS osteosarcoma cells. Mol Endocrinol 19: 1555-1568, 2005.

19. Solakidi S, Psarra AM and Sekeris CE: Differential subcellular distribution of estrogen receptor isoforms: localization of ERalpha in the nucleoli and ERbeta in the mitochondria of human osteosarcoma SaOS-2 and hepatocarcinoma HepG2 cell lines. Biochim Biophys Acta 1745: 382-392, 2005.

20. Luo XH and Liao EY: Effects of estriol on the proliferation and differentiation of human osteoblastics MG63 cells. Endocr Res 29: 343-351, 2003.

21. Berman E, Adams M, Duiguo-Osterndorf R, Godfrey L, Clarkson B and Andreeff M: Effect of tamoxifen on cell lines displaying the multidrug-resistant phenotype. Blood 77: 818-825, 1991.

22. Kang Y and Perry RR: Modulatory effects of tamoxifen and recombinant human alpha-interferon on doxorubicin resistance. Cancer Res 53: 3040-3045, 1993.

23. Kirk J, Houlbrook S, Stuart NSA, Stratford IJ, Harris AL and Carmichael J: Differential modulation of doxorubicin toxicity to multidrug and intrinsically drug resistant cell lines by anti-oestrogens and their major metabolites. Br J Cancer 67: 1189-1195, 1993.

24. O'Brian CA, Liskamp RM, Solomon DH and Weinstein IB. Inhibition of protein kinase $C$ by tamoxifen. Cancer Res 45 : 2462-2465, 1985.

25. Lam HY: Tamoxifen is a calmodulin antagonist in the activation of cAMP phosphodiesterase. Biochem Biophys Res Commun 118: 27-32, 1984.

26. Huynh TH, Tetenes E, Wallace L and Pollak M: In vivo inhibition of insulin-like growth factor I gene expression by tamoxifen. Cancer Res 53: 1727-1730, 1993.

27. Noguchi S, Motomura K, Inaji H, Imalka S and Koyama H: Down-regulation of transforming growth factor-alpha by tamoxifen in human breast cancer. Cancer 72: 131-136,1993.

28. Butta A, MacLennan K, Flanders KC, Sacks NP, Smith I, McKinna A, Dowsett M, Wakefield LM, Sporn MB, Baum M, et al: Induction of transforming growth factor beta 1 in human breast cancer in vivo following tamoxifen treatment. Cancer Res 52: 4261-4264, 1992.

29. Baral E, Nagy E and Berczi I: Modulation of natural killer cell-mediated cytotoxicity by tamoxiefn and estradiol. Cancer 75 : 591-599, 1995.

30. Couldwell WT, Hinton DR, He S, Chen TC, Sebat I, Weiss MH and Law RE: Protein kinase $\mathrm{C}$ inhibitors induce apoptosis in human malignant glioma cell lines. FEBS Lett 345: 43-46, 1994.

31. Gelmann EP: Tamoxifen induction of apoptosis in estrogen receptor-negative cancers: New tricks for an old dog. J Natl Cancer Inst 88: 224-226, 1996.

32. Clarke R, van den Berg HW and Murphy RF: Reduction of the membrane fluidity of human breast cancer cells by tamoxifen and 17 beta-estradiol. J Natl Cancer Inst 82: 1702-1705, 1990.

33. Del Prete SA, Maurer LH, O'Donnel J, Forcier RJ and LeMarbre P: Combination chemotherapy with cisplatin, carmustine, dacarbazine, and tamoxifen in metastatic melanoma. Cancer Treat Rep 68: 1403-1405, 1984.

34. Cocconi G, Bella M, Calabresi F, Tonato M, Canaletti R, Boni C, Buzzi F, Ceci G, Corgna E, Costa P, et al: Treatment of metastatic malignant melanoma with dacarbazine plus tamoxifen. N Engl J Med 327: 516-523, 1992. 
35. Vertosick FT Jr, Selker RG, Pollack IF and Arena V: The treatment of intracranial malignant glioma using orally administered tamoxifen therapy: preliminary results in a series of 'failed' patients. Neurosurgery 30: 897-903, 1992.

36. Narasimhan P: Tamoxifen in the treatment of refractory lymphoma. N Engl J Med 311: 1258-1259, 1984.

37. Ferguson PJ, Brisson AR, Koropatnick J and Vincent MD: Enhancement of cytotoxicity of natural product drugs against multidrug resistant variant cell lines of human head and neck squamous cell carcinoma and breast carcinoma by tesmilifene. Cancer Lett 274: 279-289, 2009.

38. Singh MN, Martin-Hirsch PL and Martin FL: The multiple applications of tamoxifen: an example pointing to SERM modulation being the aspirin of the 21st century. Med Sci Monit 14: RA144-RA148, 2008

39. Kang Y, Cortina R and Perry RR: Role of c-myc in tamoxifen induced apoptosis in estrogen-independent breast cancer cells. J Natl Cancer Inst 88: 279-284, 1996.

40. Incles CM, Schultes CM, Kelland LR and Neidle S: Acquired cellular resistance to flavopiridol in a human colon carcinoma cell line involves up-regulation of the telomerase catalytic subunit and telomere elongation. Sensitivity of resistant cells to combination treatment with a telomerase inhibitor $1 . \mathrm{Mol}$ Pharmacol 64: 1101-1108, 2003.
41. Cory $\mathrm{S}$ and Adams JM: Killing cancer cells by flipping the Bcl-2/Bax switch. Cancer Cell 8: 5-6, 2005.

42. Korsmeyer SJ, Shutter JR, Veis DJ, et al: Bcl-2/Bax: a rheostat that relgulates an anti-oxidant pathway and cell death. Semin Cancer Biol 4: 327-332,1993.

43. Agostinis P, Vantieghem A, Merlevede W and de Witte PA: Hypericin in cancer treatment: more light on the way. Int J Biochem Cell Biol 34: 221-241, 2002.

44. Mandlekar S and Kong AN: Mechanism of tamoxifen-induced apoptosis. Apoptosis 6: 469-477. 2001.

45. Cheng AL, Chuang SE, Fine RL, Yeh KH, Liao CM, Lay JD and Chen DS: Inhibition of the membrane translocation and activation of protein kinase $\mathrm{C}$, and potentiation of doxorubicin-induced apoptosis of hepatocellular carcinoma cells by tamoxifen. Biochem Pharmacol 55: 523-531, 1998. 